\title{
Synthesis of Immunoglobulin G by Pokeweed Mitogen- or Epstein-Barr Virus-stimulated Human B Cells In Vitro Is Restricted to the Ecto-5'-Nucleotidase Positive Subset
}

\author{
Linda F. Thompson and Julie M. Ruedi \\ Department of Immunology, Research Institute of Scripps Clinic, La Jolla, California 92037
}

\begin{abstract}
Ecto-5'-nucleotidase (ecto-5'-NT) is believed to be a maturation marker for human B lymphocytes because its expression increases during normal development and is reduced in many patients with B cell immunodeficiencies. To determine whether this enzyme defines functional subsets of $B$ lymphocytes, human peripheral blood B cells, separated into ecto-5'-NT positive and negative populations by using goat anti-5'-NT antibodies and the fluorescence-activated cell sorter, were compared for their ability to secrete polyclonal immunoglobulin. Both populations synthesized equivalent quantities of IgM in response to a $T$ cell-dependent $(P W M)$ or $T$ cell-independent (EBV) stimulator of polyclonal immunoglobulin biosynthesis. However, ecto- $5^{\prime}-\mathrm{NT}^{+}$B lymphocytes synthesized 8- to 26-fold more IgG per cell than ecto-5' $-\mathrm{NT}^{-} \mathrm{B}$ cells. These data provide the first direct evidence that ecto- $5^{\prime}-\mathrm{NT}$ is a marker for the functional maturation of human $B$ cells and support the hypothesis that ecto- 5 '-NT deficiency in patients with hypogammaglobulinemia results from a block in B lymphocyte maturation.
\end{abstract}

\section{Introduction}

Ecto-5'-nucleotidase (ecto- $\left.5^{\prime}-\mathrm{NT}\right)^{1}$ is an enzyme located on the external surface of the majority of adult human peripheral blood B cells $(1,2)$. This enzyme is thought to be a B lymphocyte maturation marker $(3,4)$, because its expression increases during B cell development. Ecto-5'-NT activity in fetal spleen and cord blood B cells is about one-fifth that in adult peripheral blood B cells $(1,3,4)$. Cord blood B cells are functionally immature in that they can synthesize only IgM (but not IgG) after stimulation in vitro with EBV (5). Ecto-5'-NT activity increases to near adult levels during the first six months of life

This work was presented in preliminary form at the 18 th International Leucocyte Culture Conference in La Grande Motte, France, June 1987 and at the UCLA Symposium on B Cell Development in Taos, NM, February 1988.

Address reprint requests to Dr. Linda F. Thompson, Department of Immunology, IMM-1, Scripps Clinic and Research Foundation, 10666 N. Torrey Pines Road, La Jolla, CA 92037.

Received for publication 18 February 1988.

1. Abbreviations used in this paper: BBS, borate-buffered saline; CVI, common variable immunodeficiency; ecto-5'-NT, ecto-5'-nucleotidase; $E_{N}$, neuraminadase-treated sheep erythrocytes; FITC, fluorescein isothiocyanate; $\mathrm{PE}$, phycoerythrin.

J. Clin. Invest.

(c) The American Society for Clinical Investigation, Inc.

0021-9738/88/09/0902/04 \$2.00

Volume 82, September 1988, 902-905
(6). This increase in enzyme activity precedes the time that infants' B cells mature and acquire the ability to synthesize $\mathrm{IgG}$ in vitro in response to EBV. The ecto-5'-NT activity in B cells from many patients with common variable immunodeficiency (CVI) is also markedly reduced $(1,4)$, and although such patients can occasionally synthesize some IgM in response to PWM or EBV, they uniformly fail to synthesize IgG (reference 1 and Thompson, L. F., unpublished observations).

We recently described the use of specific goat antibodies to detect cell surface 5 -NT by indirect immunofluorescence (2, 7). As was previously found by histochemical staining (1), ecto- $5^{\prime}-\mathrm{NT}$ is expressed on $\sim 80 \%$ of adult peripheral blood B cells. To determine whether ecto-5'-NT expression defines functional subpopulations of human B cells, we used our antibodies to isolate highly purified ecto-5'-NT positive and negative B cell preparations. These cells were then treated with both a $T$ cell-dependent (PWM) and a T cell-independent (EBV) stimulator of polyclonal Ig biosynthesis, and the quantities of IgM and IgG secreted were determined.

\section{Methods}

Cell isolation. PBL were isolated from heparinized blood of healthy adult donors by dextran sedimentation, carbonyl iron treatment to remove monocytes, and Ficoll-Hypaque density gradient centrifugation. $T$ cells were isolated by one cycle of rosetting with neuraminidase-treated sheep erythrocytes, $E_{N}$, followed by Ficoll-Hypaque density gradient centrifugation. $\mathrm{E}_{\mathrm{N}}$ were lysed with $0.83 \% \mathrm{NH}_{4} \mathrm{Cl}$. Non- $\mathrm{T}$ (B-enriched) cells were isolated at the interface of the second FicollHypaque gradient (8). Monocytes were isolated from PBMC at the interface between 0 and $50 \%$ Percoll on a discontinuous gradient (9). These preparations contained $>80 \%$ monocytes as judged by nonspecific esterase staining (10).

Preparation of the antiserum, immunofluorescence, and cell sorting. The anti-5'-NT antiserum was prepared by immunizing a goat with highly purified human placental $5^{\prime}-\mathrm{NT}$ and absorbed as previously described (7). IgG was isolated by precipitation with $50 \%$ saturated ammonium sulfate and DEAE cellulose chromatography. The IgG eluting at $0.015 \mathrm{M}$ phosphate, $\mathrm{pH} 8.0$, was digested with pepsin at $\mathrm{pH}$ 3.8 to produce $F\left(a b^{\prime}\right)_{2}$ fragments. To detect cell surface 5 '-NT, lymphocytes were incubated with $\mathrm{F}\left(\mathrm{ab}^{\prime}\right)_{2}$ anti-5'-NT at $250 \mu \mathrm{g} / \mathrm{ml}$ followed by affinity-purified $F\left(a^{\prime}\right)_{2}$ rabbit anti-goat IgG, which had been absorbed on a Cohn II-Sepharose column and then biotinylated (CooperBiomedical, Malvern, PA), and fluorescein isothiocyanate (FITC) avidin (CooperBiomedical) (7). For two-color sorts, the cells were also stained with Leu 12 (anti-CD19; Becton, Dickinson \& Co., Oxnard, CA) followed by phycoerythrin (PE) anti-mouse kappa (Becton, Dickinson \& Co.). The cells were washed once with RPMI + 2.5\% FCS

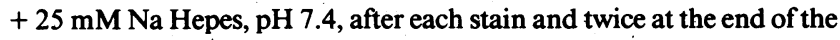
staining procedure. The cells were kept on ice in the same medium until they were sorted.

The stained cells were separated into $\mathrm{Fl}^{+}$and $\mathrm{Fl}^{-}$populations using the FACSTAR fluorescence-activated cell sorter (Becton, Dickinson \& Co.) equipped with an argon ion laser (Spectra-Physics, Inc., Mountain 
View, CA). FITC and PE were excited at $488 \mathrm{~nm}$ and their fluorescent emissions were distinguished with $530 \pm 15$ - and $575 \pm 14-\mathrm{nm}$ band pass filters. The overlap in emissions of FITC and PE was corrected by electronic compensation. The sorting gates were chosen so that the positive and negative populations were $>95 \%$ pure when reanalyzed. After being sorted, the cells were $>97 \%$ viable as determined by trypan blue dye exclusion.

PWM stimulation. 500,000 non-T (B-enriched) cells, 500,000 autologous irradiated (3,000 rads) $\mathrm{T}$ cells, and $10^{4}$ monocytes were incubated in the presence and absence of PWM (1:50 final dilution in culture; Gibco Laboratories, Grand Island, NY) in round-bottomed tubes in a total volume of $1.0 \mathrm{ml}$ of RPMI $1640+10 \%$ FCS. After $7 \mathrm{~d}$ at $37^{\circ} \mathrm{C}$ in an humidified atmosphere of $95 \%$ air and $5 \% \mathrm{CO}_{2}$, the cells were centrifuged and the supernatants were collected for quantitation of IgM and IgG secreted. In some experiments, the volume of the cultures was reduced to $0.5 \mathrm{ml}$, but the cell concentrations remained constant.

EBV stimulation. 500,000 non-T (B-enriched) cells and $10^{4}$ monocytes were incubated in the presence and absence of $20 \%(\mathrm{vol} / \mathrm{vol})$ EBV-containing supernatant from B 95-8 cells in round-bottomed tubes in a total volume of $1.0 \mathrm{ml}$ of RPMI $1640+10 \%$ FCS. After $10 \mathrm{~d}$ at $37^{\circ} \mathrm{C}$ in an humidified atmosphere of $95 \%$ air and $5 \% \mathrm{CO}_{2}$, the cells were centrifuged and the supernatants were collected for quantitation of IgM and IgG secreted. In some experiments, the volume of the cultures was reduced to $0.5 \mathrm{ml}$, but the cell concentrations remained constant.

Quantitation of IgM and IgG in culture supernatants. The quantities of IgM and IgG in culture supernatants were measured with a solid-phase enzyme immunoassay. Wells of U-bottom polyvinylchloride plates (Dynatech Laboratories, Inc., Alexandria, VA) were coated for $5 \mathrm{~h}$ at room temperature with $100 \mu \mathrm{l}$ of affinity-purified goat antihuman IgM or IgG (Southern Biotechnology Associates, Birmingham, $\mathrm{AL}$ ) at $5 \mu \mathrm{g} / \mathrm{ml}$ in borate-buffered saline (BBS). The wells were then washed three times with Blotto ( $50 \mathrm{~g}$ nonfat dry milk, $0.1 \mathrm{ml}$ antifoam A [Sigma Chemical Co., St. Louis, MO], and $0.01 \%$ thimerosal in 1 liter BBS) and then blocked with $200 \mu \mathrm{l}$ of Blotto/well for $1 \mathrm{~h}$ at room temperature. Culture supernatants or Ig standards, diluted in Blotto, were then added to wells $(100 \mu \mathrm{l} /$ well $)$ and incubated overnight at $4^{\circ} \mathrm{C}$. After five washes with Blotto, the wells were incubated with $100 \mu \mathrm{l}$ of alkaline phosphatase-conjugated affinity purified goat anti-human Ig (Tago, Inc., Burlingame, $\mathrm{CA}$ ) for $3 \mathrm{~h}$ at $37^{\circ} \mathrm{C}$. After five more washes with Blotto, the wells were treated with $100 \mu \mathrm{l}$ of $p$-nitrophenylphosphate (Sigma Chemical Co., $1 \mathrm{mg} / \mathrm{ml}$ in $0.1 \mathrm{M}$ glycine, $0.001 \mathrm{M}$ $\mathrm{MgCl}_{2}$, and $0.001 \mathrm{M} \mathrm{ZnCl}_{2}$, $\mathrm{pH} 9.45$ ). Color development then proceeded for $\sim 15-30 \mathrm{~min}$ at room temperature, after which the reaction was terminated by the addition of $25 \mu \mathrm{l} 4 \mathrm{~N} \mathrm{NaOH} /$ well. Optical density at $405 \mathrm{~nm}$ was measured with a microelisa analyzer (Dynatech Laboratories, Inc.). All supernatants were tested at three serial dilutions in duplicate. The standards were the Hyland International Reference Serum for IgM and a Cohn II fraction of human serum for IgG (gift of Dr. Hans Spiegelberg, Scripps Clinic and Research Foundation). The ranges of concentrations included in the standard curves were $250-32,000 \mathrm{pg} / \mathrm{ml}$ for IgM and $1,000-125,000 \mathrm{pg} / \mathrm{ml}$ for IgG.

\section{Results and Discussion}

Non-T (B-enriched) cells were sorted into ecto-5'-NT positive and negative populations and compared for their ability to synthesize polyclonal IgM and IgG in response to PWM or EBV (Table I). The results are expressed as nanograms of IgM or IgG secreted $/ 10^{6} \mathrm{~B}$ cells. In PWM-stimulated cultures, ecto- $5^{\prime}-\mathrm{NT}^{+}$B cells synthesized eightfold more IgG per B cell, but only one-third as much IgM as ecto- $5^{\prime}-\mathrm{NT}^{-} \mathrm{B}$ cells. In EBV-stimulated cultures, ecto- $5^{\prime}-\mathrm{NT}^{+} \mathrm{B}$ cells synthesized 12fold more IgG per B cell, but only $60 \%$ as much IgM as ecto- $5^{\prime}-\mathrm{NT}^{-}$B cells. The ecto- $5^{\prime}-\mathrm{NT}^{+}$population contained
Table I. Ability of Ecto-5'-NT $T^{+}$and Ecto-5'-NT ${ }^{-}$Non-T Cells to Synthesize Polyclonal Ig in Response to PWM and EBV

\begin{tabular}{|c|c|c|c|c|}
\hline \multirow[t]{2}{*}{ A. Stimulation with $\mathrm{PWM}^{*}$} & \multicolumn{2}{|c|}{-PWM } & \multicolumn{2}{|c|}{$+\mathrm{PWM}^{*}$} \\
\hline & IgM & $\operatorname{IgG}$ & IgM & IgG \\
\hline & \multicolumn{4}{|c|}{$n g / 10^{6} B$ cells in $7 d$} \\
\hline Untreated non-T cells & 30 & 200 & 820 & 1,040 \\
\hline $5^{\prime}-\mathrm{NT}^{+}$non-T cells & $<3$ & 5 & 80 & 800 \\
\hline $5^{\prime}-\mathrm{NT}^{-}$non-T cells & 8 & 12 & 240 & 100 \\
\hline
\end{tabular}

B. Stimulation with $\mathrm{EBV}^{\S}$

\begin{tabular}{|c|c|c|c|c|}
\hline & \multicolumn{2}{|c|}{$-\mathrm{EBV}$} & \multicolumn{2}{|c|}{$+E B V^{\prime \prime}$} \\
\hline & IgM & IgG & IgM & $\lg G$ \\
\hline & \multicolumn{4}{|c|}{$n g / 10^{6} \mathrm{~B}$ cells in $10 \mathrm{~d}$} \\
\hline Untreated non-T cells & 11 & 110 & 4,080 & 4,510 \\
\hline $5^{\prime}-\mathrm{NT}^{+}$non-T cells & 4 & $<3$ & 2,240 & 11,340 \\
\hline $5^{\prime}-\mathrm{NT}^{-}$non-T cells & $<6$ & $<6$ & 4,030 & 970 \\
\hline
\end{tabular}

* $5 \times 10^{5}$ non-T cells, $5 \times 10^{5}$ autologous irradiated $\mathrm{T}$ cells, and $10^{4}$ monocytes were incubated in the presence and absence of PWM in round-bottomed tubes in $1.0 \mathrm{ml}$ of RPMI + 10\% FCS for $7 \mathrm{~d}$.

${ }^{\ddagger}$ Net IgM or IgG synthesized; i.e., -PWM values are subtracted. $\$ 5 \times 10^{5}$ non-T cells and $10^{4}$ monocytes were incubated in the presence and absence of $20 \%$ (vol/vol) EBV-containing supernatant from B 95-8 cells in round-bottomed tubes in $1.0 \mathrm{ml}$ of RPMI $+10 \%$ FCS for $10 \mathrm{~d}$.

"Net IgM or IgG synthesized; i.e., -EBV values are subtracted.

pure B cells, since B cells are the only cell type in a non- $T$ cell preparation that expresses ecto- $5^{\prime}-\mathrm{NT}$ (2). The ecto- $5^{\prime}-\mathrm{NT}^{-}$ non- $\mathrm{T}$ cells, in this experiment, were $50 \% \mathrm{~B}$ cells as determined by rosetting with ox erythrocytes coated with anti-IgM and anti-IgD (11). In other experiments when total non-T cells were sorted into ecto-5'-NT positive and negative populations, the latter group contained variable and often low percentages of $B$ cells.

To overcome this difficulty and to make sure that the lack of IgG synthesis by ecto-5'-NT ${ }^{-}$B cells did not result from suppression by non-B cells contaminating the preparations, we used two-color sorting for two experiments in which the B cells were identified by staining with anti-CD19 plus PE-antimouse kappa. We first ascertained that staining B cells with anti-CD19 did not cause spontaneous Ig secretion, nor did it inhibit their responses to PWM or EBV (data not shown). The use of the second color enabled us to sort only B cells into ecto-5'-NT ${ }^{+}$and ecto-5'-NT ${ }^{-}$populations. Fig. 1 shows a twocolor fluorescence contour plot of non-T cells stained with goat anti-5'-NT antibodies in green and anti-CD19 in red. The positions of the sorting gates are shown by the boxes. Fig. 2 shows immunofluorescence histograms of the sorted populations. Both populations contained $>98 \%$ B cells as judged by staining with anti-CD19 and were $>95 \%$ pure with respect to the expression of ecto-5'-NT. As Table II illustrates, in this experiment ecto- $5^{\prime}-\mathrm{NT}^{+} \mathrm{B}$ cells synthesized more IgM and IgG than ecto-5'-NT ${ }^{-}$B cells in response to both PWM and EBV, but the difference was more pronounced for IgG. In PWMstimulated cultures, ecto-5'-NT ${ }^{+}$B cells synthesized 2-fold 


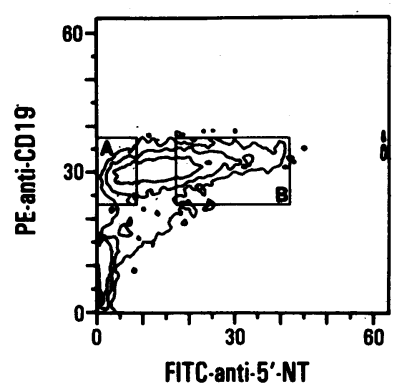

Figure 1. Two-color immunofluorescence contour map of human peripheral blood non-T cells stained with anti-5'-NT antibodies in green vs. anti-CD19 in red. The sorting gates are shown in the boxes: $(A)$ ecto- $5^{\prime}-\mathrm{NT}^{-} \mathrm{B}$ cells and $(B)$ ecto- $5^{\prime}-\mathrm{NT}^{+} \mathrm{B}$ cells.

more IgM and 26-fold more IgG per cell than the ecto- $5^{\prime}-\mathrm{NT}^{-}$ $B$ cells. In EBV-stimulated cultures, ecto- $5^{\prime}-\mathrm{NT}^{+} \mathrm{B}$ cells synthesized 1.6-fold more IgM and 8-fold more IgG per cell than ecto- $5^{\prime}-\mathrm{NT}^{-} \mathrm{B}$ cells.

Note that staining non-T cells with anti-5'-NT antibodies apparently enhanced IgM (but not IgG) synthesis after PWM or EBV stimulation by approximately twofold (Table II). In a preliminary examination of this phenomenon, anti-5'-NT antibodies were included in the culture medium during the entire 7-d stimulation of PBMC with PWM. The response varied from donor to donor, but in the five individuals studied, the average enhancement in IgM synthesis in the cultures treated with anti-5'-NT antibodies was 6.5 -fold. IgG synthesis also increased 2-fold. These data suggest that ecto-5'-NT may play a direct role in B cell activation. Experiments are now in progress to determine whether the interaction of anti-5'-NT antibodies with $B$ cells triggers known biochemical pathways of B cell activation.

In summary, although both ecto- $5^{\prime}-\mathrm{NT}^{+}$and ecto- $5^{\prime}-\mathrm{NT}^{-} \mathrm{B}$ cells can synthesize IgM in response to either PWM or EBV, the synthesis of IgG in vitro is largely restricted to the ecto-5'$\mathrm{NT}^{+}$subpopulation. Our data, therefore, provide the first direct evidence that ecto- $5^{\prime}-\mathrm{NT}$ is a marker for the functional maturation of human B cells. In fact, since $\sim 80 \%$ of adult peripheral blood B cells are ecto- $-5^{\prime}-\mathrm{NT}^{+}$, we calculate that in bulk cultures; $97-99 \%$ of the IgG synthesized in response to PWM or EBV is made by ecto- $5^{\prime}-\mathrm{NT}^{+} \mathrm{B}$ cells. Similar calcula-

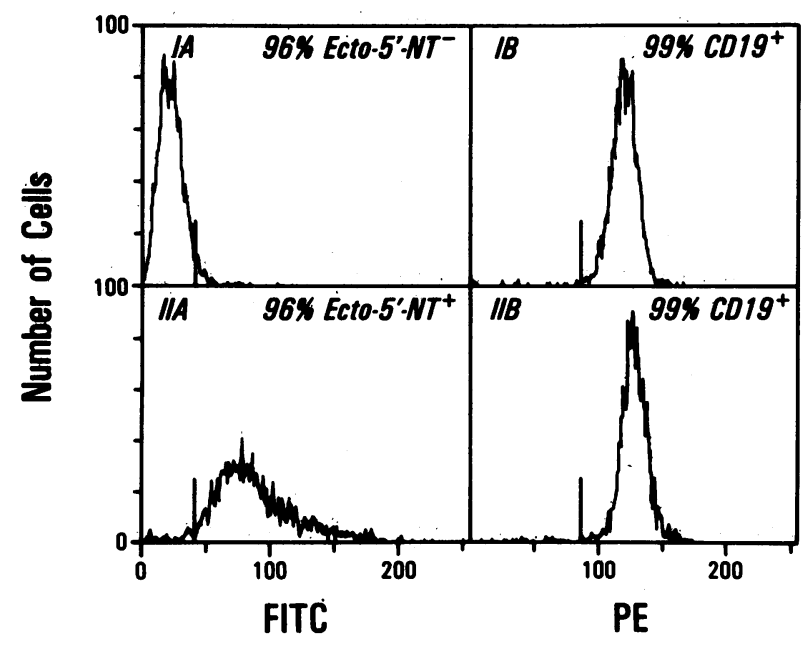

Figure 2. Reanalysis of sorted ecto-5'-NT positive and negative populations. I. Ecto-5'-NT' $B$ cells: $(A)$ anti-5'-NT and $(B)$ anti-CD19. II. Ecto-5'-NT ${ }^{+}$B cells: $(A)$ anti-5'-NT and $(B)$ anti-CD19.
Table II. Ability of Ecto-5'-NT ${ }^{+}$and Ecto- $5^{\prime}-N T^{-} B$ Cells to Synthesize Polyclonal Ig in Response to PWM and EBV

\begin{tabular}{|c|c|c|c|c|}
\hline \multirow[t]{2}{*}{ A. Stimulation with PWM* } & \multicolumn{2}{|c|}{$-\mathbf{P W M}$} & \multicolumn{2}{|c|}{$+\mathrm{PWM}^{*}$} \\
\hline & IgM & IgG & IgM & IgG \\
\hline & \multicolumn{4}{|c|}{ ng Ig/10 $\mathrm{B}$ cells in $7 \mathrm{~d}$} \\
\hline Untreated B cells & 310 & 600 & 3,500 & 11,200 \\
\hline \multicolumn{5}{|l|}{ Stained, but not sorted B } \\
\hline cells & 260 & 530 & 7,200 & 13,500 \\
\hline Ecto- $5^{\prime}-\mathrm{NT}^{+}$B cells & 44 & 70 & 2,200 & 18,700 \\
\hline Ecto- $5^{\prime}-\mathrm{NT}^{-} \mathrm{B}$ cells & 110 & 220 & 1,100 & 720 \\
\hline
\end{tabular}

B. Stimulation with $\mathrm{EBV}^{\S}$

\begin{tabular}{|c|c|c|}
\hline & & +EBVI" \\
\hline IgM & IgG & IgM \\
\hline
\end{tabular}

ng $\mathrm{Ig} / 10^{6} \mathrm{~B}$ cells in $10 \mathrm{~d}$

$\begin{array}{lrrrr}\text { Untreated B cells } & 230 & 480 & 1,600 & 780 \\ \text { Stained, but not sorted B } & & & & \\ \quad \text { cells } & 280 & 630 & 2,800 & 740 \\ \text { Ecto-5'-NT }^{+} \text {B cells } & 12 & 36 & 2,600 & 1,600 \\ \text { Ecto-5'-NT }^{-} \text {B cells } & 100 & 180 & 1,600 & 190\end{array}$

* $5 \times 10^{5}$ non-T cells, $5 \times 10^{5}$ autologous irradiated T cells, and $10^{4}$ monocytes were incubated in the presence and absence of PWM in round-bottomed tubes in $1.0 \mathrm{ml}$ of RPMI + 10\% FCS for $7 \mathrm{~d}$.

${ }^{\ddagger}$ Net IgM or IgG synthesized; i.e., -PWM values are subtracted.

$85 \times 10^{5}$ non-T cells and $10^{4}$ monocytes were incubated in the presence and absence of $20 \%$ (vol/vol) EBV-containing supernatant from B 95-8 cells in round-bottomed tubes in $1.0 \mathrm{ml}$ of RPMI + $10 \%$ FCS for $10 \mathrm{~d}$.

"Net IgM or IgG synthesized; i.e., -EBV values are subtracted.

tions predict that $50-85 \%$ of the IgM in such cultures is made from ecto- $5^{\prime}-\mathrm{NT}^{+} \mathrm{B}$ cells. Clearly, not all ecto- $5^{\prime}-\mathrm{NT}^{+} \mathrm{B}$ cells respond to PWM, however. Approximately $80 \%$ of adult peripheral blood B cells are ecto- $5^{\prime}-\mathrm{NT}^{+}$by either indirect immunofluorescence or histochemical staining $(1,2)$, whereas limiting dilution analysis suggests that $<1 \%$ of B cells synthesize Ig in response to stimulation with PWM (12).

Our data also clearly show that purified populations of ecto-5'-NT ${ }^{-}$B cells have a capacity to synthesize IgM. The amount synthesized, although variable from individual to individual, is similar to that of ecto- $5^{\prime}-\mathrm{NT}^{+} \mathrm{B}$ cells on a per cell basis. These results are consistent with our earlier studies of both patients with CVI and normal infants. Although ecto-5'NT-deficient B cells from most CVI patients have a markedly reduced capacity for Ig synthesis in vitro, B cells from some patients can synthesize IgM (1). Normal newborn infants' B cells have low ecto- $5^{\prime}-\mathrm{NT}$ activity and can synthesize IgM, but not IgG in response to EBV in vitro $(5,6)$. Ecto-5'-NT expression increases in the first six months of life (6) and is then maintained in the subset of B cells that is PWM-responsive. Ecto-5'-NT thus differs from other B cell maturation markers such as IgD, HB-4, Leu 8, and the mouse erythrocyte rosette receptor, which are lost as $B$ cells mature and gain the ability to respond to PWM (13-15). Therefore, analysis of ecto-5'-NT expression, especially in combination with other B cell differ- 
entiation antigens, should prove a valuable tool in delineating stages in human B cell maturation.

\section{Acknowledgments}

The authors acknowledge the excellent secretarial support of Margaret Stone, the editorial assistance of Phyllis Minick, and the technical expertise of the members of the Cell Sorting Facility.

This work was supported by grant AI-18220 and the Biomedical Research Support Program grant RR-05514 from the National Institutes of Health. This is publication No. 5207a-IMM from the Research Institute of Scripps Clinic.

\section{References}

1. Thompson, L. F., J. M. Ruedi, R. D. O'Connor, and J. F. Bastian. 1986. Ecto-5'-nucleotidase expression during human $B$ cell development. An explanation for the heterogeneity in B lymphocyte ecto-5'-nucleotidase activity in patients with hypogammaglobulinemia. J. Immunol. 137:2496-2500.

2. Thompson, L. F., J. M. Ruedi, M. G. Low, and L. T. Clement. 1987. Distribution of ecto-5'-nucleotidase on subsets of human $T$ and B lymphocytes as detected by indirect immunofluorescence using goat antibodies. J. Immunol. 139:4042-4048.

3. Boss, G. R., L. F. Thompson, H. L. Spiegelberg, T. A. Waldmann, R. D. O'Connor, R. N. Hamburger, and J. E. Seegmiller. 1979. Lymphocyte ecto-5'-nucleotidase as a marker of $\mathrm{B}$ cell maturation. Trans. Assoc. Am. Phys. 91:309-315.

4. Rowe, M., G. C. DeGast, T. A. E. Platts-Mills, G. L. Asherson, A. D. B. Webster, and S. M. Johnson. 1980. Lymphocyte 5'-nucleotidase in primary hypogammaglobulinemia and cord blood. Clin. Exp. Immunol. 39:337-343.

5. Tosato, G., I. T. Magrath, I. R. Koski, N. J. Dooley, and R. M. Blaese. 1980. B cell differentiation and immunoregulatory $T$ cell function in human cord blood lymphocytes. J. Clin. Invest. 66:383-388.
6. Bastian, J. F., J. M. Ruedi, G. A. MacPherson, H. E. Golembesky, R. D. O'Connor, and L. F. Thompson. 1984. Lymphocyte ecto-5'-nucleotidase activity in infancy: increasing activity in peripheral blood B cells precedes their ability to synthesize IgG in vitro. $J$. Immunol. 132:1767-1772.

7. Thompson, L. F., J. M. Ruedi, and M. G. Low. 1987. Purification of 5'-nucleotidase from human placenta after release from plasma membranes by phosphatidylinositol-specific phospholipase C. Biochem. Biophys. Res. Commun. 145:118-125.

8. Thompson, L. F., A. Saxon, R. D. O'Connor, and R. I. Fox. 1983. Ecto-5'-nucleotidase activity in human T cell subsets. J. Clin. Invest. 71:892-899.

9. Ferreri, N. R., W. C. Howland, and H. L. Spiegelberg. 1986. Release of leukotrienes C4 and B4 and prostaglandin E2 from human monocytes stimulated with aggregated IgG, IgA, and IgE. J. Immunol. 136:4188-4193.

10. Koski, I. R., D. G. Poplack, and R. M. Blaese. 1976. A nonspecific esterase stain for the identification of monocytes and macrophages. In Methods in Cell-mediated and Tumor Immunity. B. R. Bloom and J. R. David, editors. Academic Press, Inc., New York. 359-362.

11. Spiegelberg, H. L., and P. M. Dainer. 1979. Fc receptors for IgG, IgM and IgE on human leukaemic lymphocytes. Clin. Exp. Immunol. 35:286-295.

12. Thiele, C. J., and R. H. Stevens. 1980. Antibody potential of human peripheral blood lymphocytes differentially expressing surface membrane IgM. J. Immunol. 124:1898-1904.

13. Lucivero, G., A. R. Lawton, and M. D. Cooper. 1981. Rosette formation with mouse erythrocytes defines a population of human B lymphocytes unresponsive to pokeweed mitogen. Clin. Exp. Immunol. 45:185-190.

14. Tedder, T. F., L. T. Clement, and M. D. Cooper. 1985. Development and distribution of a human $B$ cell subpopulation identified by the HB-4 monoclonal antibody. J. Immunol. 134:1539-1544.

15. Kansas, G. S., G. S. Wood, and E. G. Engleman. 1985. Maturational and functional diversity of human B lymphocytes delineated with anti-Leu-8. J. Immunol. 134:3003-3006. 